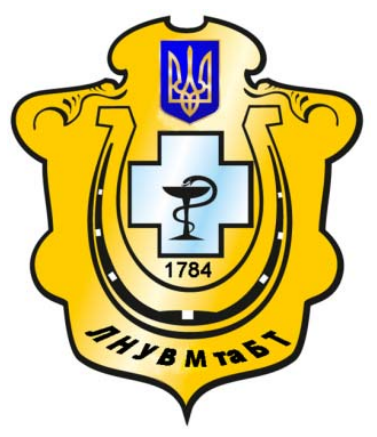

Науковий вісник Львівського національного університету ветеринарної медицини та біотехнологій імені С.З. Гжицького

Scientific Messenger of Lviv National University of Veterinary Medicine and Biotechnologies named after S.Z. Gzhytskyj

doi:10.15421/nvlvet7414

ISSN 2519-2698 print

ISSN 2518-1327 online

$\underline{\text { http://nvlvet.com.ua/ }}$

UDC 636.4.082.25 : 575.22

\title{
Genetic polymorphism of the Landrace pig based on microsatellite markers
}

\author{
S.I. Lugovoy, S.S. Kramarenko, V.Ya. Lykhach \\ Lugsergey23@gmail.com \\ Mykolayiv National Agrarian University, \\ Georgy Gongadze Str., 9, Mykolayiv, Ukraine, 54020
}

\begin{abstract}
The aim of this study was to analyze the genetic variability and population structure of the Landrace population by using 12 microsatellite markers. A total of 90 pigs representing one commercial breed (Landrace) were sampled. Twelve microsatellite loci (SW24, S0155, SW72, SW951, S0386, S0355, SW240, SW857, S0101, SW936 SW911 and S0228) were selected and belong to the list of microsatellite markers recommended by FAO/ISAG.

GenAIEx software was used to calculate the allele frequencies, effective number of alleles (Ae), observed (Ho) and expected (He) heterozygosity, within-population inbreeding estimate (Fis), Shannon's information index $\left(I_{S h}\right)$. Overall allele frequency values ranged from 0.006 to 0.9333 (at allele SW951120). The number of observed alleles (Na) detected ranged from 5 (S0155 and SW911) to 13 (SW72), with an overall mean of $9.00 \pm 0.80$ and a total of 108 alleles were observed at these loci. However, the effective number of alleles (Ae) ranged from 1.57 (SW951) to 5.49 (SW240) with a mean of $3.29 \pm 0.33$. Shannon's information index (I $\left.I_{S h}\right)$ which measures the level of diversity, was sufficiently high-from 0.79 (for SW951) to 2.01 (for SW240) - with a mean of $1.43 \pm 0.09$. The overall means for observed (Ho) and expected (He) heterozygosities were $0.578 \pm 0.009$ and $0.662 \pm 0.004$, respectively, which ranged from 0.307 (SW951) to 0.814 (SW857) and 0.361 (SW951) to 0.818 (SW240), respectively. Of the 12 microsatellites analyzed using Fisher's exact test, 50\% were in Hardy-Weinberg equilibrium, and 6 were out of equilibrium $(P<0.05)$.

Three mutation models namely, infinite allele model (I.A.M.), two phase model (T.P.M.), stepwise mutation model (S.M.M.) were estimated using the BOTTLENECK software. The results are indicated that the Landrace pig population is non-bottlenecked and remained at mutation-drift equilibrium.

The study stands first in genetic characterization of the Ukrainian Landrace pig population through microsatellite markers. The various parameters and values used to quantify genetic variability, such as the high mean (and effective) number of alleles and the expected and observed heterozygosities, indicated high genetic variability in the Ukrainian Landrace pigs. The population has not undergone any recent and/or sudden reduction in the effective population size and remained at mutation-drift equilibrium.

Key words: genetic polymorphism, microsatellite loci, pigs, Landrace breed
\end{abstract}

\section{Генетический полиморфизм свиней породы ландрас на основе микросателлитных маркеров}

\author{
С.И. Луговой, С.С. Крамаренко, В.Я. Лихач \\ Lugsergey23@gmail.com
}

Николаевский национальный аграрный университет, ул. Георгия Гонгадзе, 9, г. Николаев, 54020, Украина

\begin{abstract}
Цель этого исследования состояла в том, чтобы проанализировать генетическую изменчивость и структуру популяции свиней породы ландрас с использованием 12 микросателлитных локусов. Всего было исследовано 90 свиней, представляющих одну коммерческую породу (ландрас). Были выбраны 12 микросателлитных локусов (SW24, S0155, SW72, SW951, S0386, S0355, SW240, SW857, S0101, SW936 SW911 и S0228), которые входят в список микросателлитных маркеров, рекомендованных ФАO/ISAG.
\end{abstract}

\section{Citation:}

Lugovoy, S.I., Kramarenko, S.S., Lykhach, V.Ya. (2017). Genetic polymorphism of the Landrace pig based on microsatellite markers. Scientific Messenger LNUVMBT named after S.Z. Gzhytskyj, 19(74), 63-66. 
Для расчета частот аллелей, эффективного числа аллелей (Ае), наблюдаемой (Но) и ожидаемой (Не) гетерозиготности, оиенки инбридинга (Fis), информационного индекса Шеннона $\left(I_{S h}\right)$ использовалось программное обеспечение GепAIEx. B иелом частота аллелей варьировала от 0,006 до 0,9333 (для аллеля $S W 951^{120}$ ). Число аллелей (Na) варьировало от 5 ( $(S 0155$ и

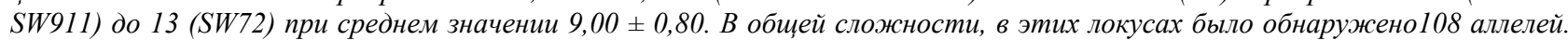
Однако эффективное число аллелей (Ае) варьировало от 1,57 (SW951) до 5,49 (SW240) при среднем значении 3,29 $\pm 0,33$. Информационный индекс Шеннона $\left(I_{S h}\right)$, который свидетельствует об уровне разнообразия, был достаточно высоким - от 0,79 (для SW951) до 2,01 (для SW240) при среднем значении 1,43 0,09. Средние значения оченок наблюдаемой (Но) и ожидаемой (Не) гетерозиготности составляли 0,578 \pm 0,009 и 0,662 $\pm 0,004$ соответственно и варьировали от 0,307 (SW951) до 0,814 (SW857) и от 0,361 (SW951) до 0,818 (SW240) соответственно. Из 12 локусов микросателлитов, проанализированных с использованием точного теста Фишера, 50\% находились в состоянии равновесия Харди-Вайнберга, а еще 6 - отклонялись от него $(P<0,05)$.

С использованием программного обеспечения ВОTTLENECK оценивались три мутационные модели, а именно: модель бесконечного числа аллелей (I.A.M.), двухфазная модель (T.P.М.), модель пошаговой мутачии (S.M.M.). Результаты показывают, что для популяиии свиней породы ландрас не отмечено bottleneck-эффекта и она находится в состоянии равновесия между мутаиионным проиессом и дрейфом генов.

В исследовании впервые приведена генетическая характеристика украинской популяиии свиней породы ландрас с использованием полиморфизма микросателлитных локусов. Различные параметры, используемые для количественной оценки генетической изменчивости, дают высокие оиенки для среднего (и эффективного) числа аллелей, ожидаемой и наблюдаемой гетерозиготности, что указывает на высокую генетическую изменчивость украинской популяции свиней породы ландрас. Популяиия не претерпела каких-либо недавних и/или внезапных сокращений эффективной численности и оставалась 8 состоянии равновесия между мутационным процессом и дрейфом генов.

Ключевые слова: генетический полиморфизм, микросателлитные локусы, свиньи, порода ландрас

\title{
Генетичний поліморфізм свиней породи ландрас на основі мікросателітних маркерів
}

\author{
С.І. Луговий, С.С. Крамаренко, В.Я. Лихач \\ Lugsergey23@gmail.com
}

Миколаївський національний аграрний університет, вул. Георгія Гонгадзе, 9, м. Миколаїв, 54020, Украӥна

Мета иьього дослідження полягала в тому, щчоб проаналізувати генетичну мінливість і структуру популяиії свиней породи ландрас з використанням 12 мікросателітних локусів. Всього було досліджено 90 свиней, які представляють одну комериійну породу (ландрас). Було обрано 12 мікросателітних локусів (SW24, S0155, SW72, SW951, S0386, S0355, SW240, SW857, S0101, SW936 SW911 і S0228), які входять до списку мікросателітних маркерів, рекомендованих ФAO / ISAG.

Для розрахунку частот алелей, ефективного числа алелей (Ае), фактичної (Но) і очікуваної (Не) гетерозиготності, оцінки інбридингу (Fis), інформаційного індексу Шеннона $\left(I_{S h}\right)$. використовувалося програмне забезпечення GепAIEx. B иілому, частота алелей варіювала від 0,006 до 0,9333 (для алелі SW951 120). Число алелей (Na) варіювало від 5 (S0155 i SW911) до 13 (SW72) із середнім значенням 9,00 \pm 0,80. Загалом для иих локусів було виявлено108 алелей. Однак ефективне число алелей (Ае) варіювало від 1,57 (SW951) до 5,49 (SW240) із середнім значенням 3,29 0,33. Інформачійний індекс Шеннона (I $\left.I_{S h}\right)$ який свідчить про рівень різноманітності, був досить високим - від 0,79 (для SW951) до 2,01 (для SW240) - із середнім значенням

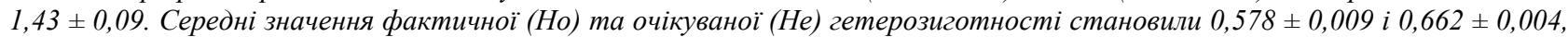
відповідно і варіювали від 0,307 (SW951) до 0,814 (SW857) і від 0,361 (SW951) до 0,818 (SW240) відповідно. Iз 12 локусів мікросателітів, проаналізованих з використанням точного тесту Фішера, 50\% перебували в стані рівноваги Харді-Вайнберга, а решта - відхилялися від нього $(P<0,05)$.

3 використанням програмного забезпечення ВОTTLENECK оиінювалися три мутаиійні моделі, а саме: модель нескінченного числа алелей (I.A.M.), двохфазна модель (T.P.М.), модель покрокової мутації (S.M.M.). Результати свідчать, щзо для популяиії свиней породи ландрас не відзначено bottleneck-ефекту і вона перебувала в стані рівноваги між мутаційним проиесом і дрейфом генів.

У дослідженні вперше наведена генетична характеристика украӥнської популяиії свиней породи ландрас з використанням поліморфізму мікросателітних локусів. Різні параметри, які використовуються для кількісної очінки генетичної мінливості, дають високі оцінки середнього (і ефективного) числа алелей, очікуваної і фактичної гетерозиготності, щьо вказуе на високу генетичну мінливість украӥнської популяиії свиней породи ландрас. Популяиія не зазнала будь-яких недавніх і/або раптових скорочень ефективної чисельності і залишалася в стані рівноваги між мутаційним процесом і дрейфом генів.

Ключові слова: генетичний поліморфізм, мікросателітні локуси, свині, порода ландрас

\section{Introduction}

In recent years, knowledge of the commercial and local pig resources of the Ukraine has increased, following a similar trend in other countries. The productive lifespan, good maternal ability and high meat production of the Landrace pigs is remarkable. In addition, the superiority of crossbreeding these pigs with Large White breeds in terms of the growth stage and weight gain of offspring is also noteworthy. However, the genetic characterization of the Landrace pigs from Ukrainian populations is still insufficient. In Ukraine, the first studies using molecular markers in pigs were done by V. Topiha et al. (Topiha et al., 2010) who analyzed a panel of five microsatellites in 241 Large White pigs.

The aim of this study was to analyze the genetic vari- 
ability and population structure of the Landrace population by using 12 microsatellite markers.

\section{Material and Methods}

A total of 90 pigs representing one commercial breed (Landrace) were sampled. The animals belonged to the breeding group of the public joint-stock company (PJSC) «Plemzavod «Stepnoy» located in Zapovitne village, Kamensko-Dniprovsky district of Zaporozhia region, Ukraine.

PCR analysis was carried out on DNA extracted from 90 ethanol-fixed small pieces of ear tissue samples. A DNA extraction using the Nexttec Clean Column kit (Nexttec, Germany) according to the manufacturer's instructions was performed.

Twelve microsatellite loci which presented reliable amplification standards (SW24, S0155, SW72, SW951, S0386, S0355, SW240, SW857, S0101, SW936 SW911 and S0228) were selected and belong to the list of microsatellite markers recommended by FAO/ISAG. The adopted strategy for the selection of the loci was to represent most of the autosomic pig chromosome.

Electrophoresis was carried out using an ABI 3130×1 Genetic Analyzer (Applied Biosystems, USA). Allele sizes of each microsatellite were determined using GeneMapper ver. 4.0 (Applied Biosystems).

All the samples were stored in the DNA Bank of the Laboratory of All-Russian Science Institute of Animal Husbandry named after L.K. Ernst (VIJ), Dubrovitzy (Russian Federation), where this experiment was developed.

GenAIEx version 6.5 (Peakall and Smouse, 2006) was used to calculate the allele frequencies, effective number of alleles $(\mathrm{Ae})$, observed $(\mathrm{Ho})$ and expected $(\mathrm{He})$ heterozygosity, within-population inbreeding estimate (Fis), Shannon's information index $\left(I_{S h}\right)$.
GENEPOP version 4.2 (Rousset, 2008) was used to perform deviations form Hardy-Weinberg equilibrium (HWE) per locus using Markov chain algorithm implemented according to authors recommendation with 10,000 dememorizations, 200 batches and 5,000 interactions per batch.

The BOTTLENECK (version 1.2.03) (Cornuet and Luikart, 1996) analysis was performed to know whether this pig population exhibits a significant number of loci with excess of heterozygosity.

\section{Results and Discussion}

The genetic diversity parameters in the Landrace pig, such as allele number, effective number of allele, observed and expected heterozygosity, within-population inbreeding estimate (Fis) and Shannon's information index are presented in Table 1.

All the loci studied were polymorphic. Overall allele frequency values ranged from 0.006 to 0.9333 (at allele SW951120). The number of observed alleles $(\mathrm{Na})$ detected ranged from 5 (S0155 and $S W 911)$ to 13 (SW72), with an overall mean of $9.00 \pm 0.80$ and a total of 108 alleles were observed at these loci. However, the effective number of alleles $(A e)$ ranged from 1.57 (SW951) to 5.49 $(S W 240)$ with a mean of $3.29 \pm 0.33$.

Shannon's information index $\left(I_{S h}\right)$ which measures the level of diversity, was sufficiently high - from 0.79 (for $S W 951$ ) to 2.01 (for $S W 240$ ) - with a mean of $1.43 \pm 0.09$. The overall means for observed $(\mathrm{Ho})$ and expected $(\mathrm{He})$ heterozygosities were $0.578 \pm 0.009$ and $0.662 \pm 0.004$, respectively, which ranged from 0.307 (SW951) to 0.814 (SW857) and 0.361 (SW951) to 0.818 (SW240), respectively. Of the 12 microsatellites analyzed using Fisher's exact test, $50 \%$ were in Hardy-Weinberg equilibrium, and 6 were out of equilibrium $(\mathrm{P}<0.05)$.

Microsatellite analysis in the Landrace pig population

\begin{tabular}{|c|c|c|c|c|c|c|c|c|}
\hline Locus & $n$ & $N a$ & $A e$ & $I_{S h}$ & $H o$ & $H e$ & Fis & $H W E$ \\
\hline$S W 24$ & 69 & 10 & 4.22 & 1.64 & 0.797 & 0.763 & -0.045 & $\mathrm{~ns}$ \\
\hline$S 0155$ & 90 & 5 & 2.52 & 1.14 & 0.589 & 0.603 & 0.024 & $\mathrm{~ns}$ \\
\hline$S W 72$ & 85 & 13 & 2.97 & 1.49 & 0.671 & 0.664 & -0.010 & $\mathrm{~ns}$ \\
\hline$S W 951$ & 88 & 7 & 1.57 & 0.79 & 0.307 & 0.361 & 0.151 & $* * *$ \\
\hline$S 0386$ & 90 & 10 & 2.75 & 1.46 & 0.578 & 0.637 & 0.093 & $\mathrm{~ns}$ \\
\hline$S 0355$ & 85 & 10 & 3.04 & 1.42 & 0.412 & 0.671 & 0.386 & $* * *$ \\
\hline$S W 240$ & 77 & 12 & 5.49 & 2.01 & 0.675 & 0.818 & 0.174 & $* * *$ \\
\hline$S W 857$ & 86 & 10 & 5.22 & 1.85 & 0.814 & 0.809 & -0.007 & $\mathrm{~ns}$ \\
\hline$S 0101$ & 87 & 6 & 3.29 & 1.30 & 0.747 & 0.696 & -0.074 & $\mathrm{~ns}$ \\
\hline$S W 936$ & 85 & 12 & 2.67 & 1.43 & 0.435 & 0.625 & 0.304 & $* * *$ \\
\hline$S W 911$ & 45 & 5 & 2.53 & 1.19 & 0.422 & 0.605 & 0.303 & $*$ \\
\hline$S 0228$ & 86 & 8 & 3.25 & 1.44 & 0.488 & 0.693 & 0.295 & $* * *$ \\
\hline
\end{tabular}

The within-population inbreeding estimates (Fis) observed at 8 loci were positive and 4 loci revealed negative with a mean of $0.133 \pm 0.046$ is indicating significant heterozygosity shortage in the Landrace pig population.

Three mutation models namely, infinite allele model (I.A.M.), two phase model (T.P.M.), stepwise mutation model (S.M.M.) were estimated using the BOTTLENECK software (Table 2). The results are indicated that the Landrace pig population is non-bottlenecked and remained at mutation-drift equilibrium.

The effective number of alleles found in this study $(3.29 \pm 0.33)$ was higher than that in the German Landrace (2.27), the Vietnam Landrace pigs (2.83) (Thuy et al., 2006). This value for the Ukrainian Landrace pigs was comparable to than that found by Vicente et al. (Vicente et al., 2008) in the Landrace pigs from Portugal (3.47). 
The average expected (0.662) and observed (0.578) heterozygosities of the Ukrainian Landrace pigs indicated a high degree of variability. The heterozygosity observed here resembled the values found for other breeds, such as the Vietnam Landrace pigs $(H e=0.600)$ (Thuy et al., 2006), the Spanish Landrace pigs $(H e=0.640)$ (Boitard et al., 2010) and the Portuguese Landrace pigs $(\mathrm{He}=0.670)$ (Vicente et al., 2008). The observed heterozygosity found in present study is also in close agreement with the reported values in Landrace $(0.522)$ by Swart et al. (Swart et al., 2010) for the Southern African domestic pigs.

Table 2

Bottleneck analysis in the Landrace pig population

\begin{tabular}{|l|c|c|c|}
\hline \multirow{2}{*}{ Model } & \multicolumn{2}{|c|}{ Sign rank test - Number of loci with heterozygosity excess } \\
\cline { 2 - 4 } & Expected & Observed & Probability \\
\hline I.A.M. & 7.16 & 4 & 0.060 \\
\hline T.P.M. & 7.14 & 4 & 0.061 \\
\hline S.M.M. & 7.10 & 1 & $<0.001$ \\
\hline
\end{tabular}

The Fis values in the sample of the Ukrainian Landrace pigs ranged from -0.074 to 0.386 . The mean within population inbreeding estimate (Fis) was 0.133 . The deficiency of heterozygotes (13.3 percent) in the Ukrainian Landrace pig population is higher to heterozygote shortfall observed in the Portuguese Landrace pig (3.8 percent) (Vicente et al., 2008) and the Spanish Landrace pigs (6.0 percent) (Boitard et al., 2010).

\section{Conclusions}

The study stands first in genetic characterization of the Ukrainian Landrace pig population through microsatellite markers. The various parameters and values used to quantify genetic variability, such as the high mean (and effective) number of alleles and the expected and observed heterozygosities, indicated high genetic variability in the Ukrainian Landrace pigs. The population has not undergone any recent and/or sudden reduction in the effective population size and remained at mutation-drift equilibrium.

\section{Researcher's perspectives}

The evaluation of pig genetic resources and the conservation of key pig populations will be important to enable the Ukrainian agriculture and food industries to respond to future changes in consumer needs. Two breeds are mainly used as maternal lines in the Ukrainian swine breeding programs: Landrace and Large White, which represent 37.3 percent and 51.8 percent of the overall germplasm used for pork production, respectively (Gladiy et al., 2015). Evaluating the genetic diversity within a breed is also a requisite for genetic conservation.

\section{Acknowledgement}

This study was performed with financial support of the Ministry of Education and Science of Ukraine (No. 0116U004760).

\section{References}

Topiha, V.S., Lugovoy, S.I., Kramarenko, S.S. (2010). Analiz geneticheskogo raznoobraziia svinei krupnoi beloi porody na osnove multilokusnykh genotipov mikrosatellitov. Visnik agrarnoy nauki Prichornomor'ia. 1(52), T. 2, 3-11 (In Russian).

Peakall, R.O.D., Smouse, P.E. (2006). GENAIEX 6: genetic analysis in Excel. Population genetic software for teaching and research. Molecular Ecology Notes. 691, 288-295.

Rousset, F. (2008). GENEPOP'007: a complete reimplementation of the GENEPOP software for Windows and Linux. Molecular Ecology Resources. 8, 103-106.

Cornuet, J.M., Luikart, G. (1996). Description and power analysis of two tests for detecting recent population bottlenecks from allele frequency data. Genetics. 144, 2001-2014.

Thuy, N.T.D., Melchinger-Wild, E., Kuss, A. W., Cuong, N.V., Bartenschlager, H., Geldermann, H. (2006). Comparison of Vietnamese and European pig breeds using microsatellites. Journal of animal science. 84 (10), 2601-2608.

Vicente, A.A., Carolino, M.I., Sousa, M.C.O., Ginja, C., Silva, F.S., Martinez, A.M., Vega-Pla, J.L., Carolino, N., Gama, L.T., (2008). Genetic diversity in native and commercial breeds of pigs in Portugal assessed by microsatellites. Journal of animal science. 86(10), 2496-2507.

Boitard, S., Chevalet, C., Mercat, M.J., Meriaux, J.C., Sanchez, A., Tibau, J., Sancristobal, M. (2010). Genetic variability, structure and assignment of Spanish and French pig populations based on a large sampling. Animal genetics. 41(6), 608-618.

Swart, H., Kotze, A., Olivier, P. A. S., Grobler, J. P. (2010). Microsatellite-based characterization of Southern African domestic pigs (Sus scrofa domestica). South African Journal of Animal Science. 40(2), 121-132.

Gladiy, M.V., Ruban, S.Y., Getya, A.A., Pryima, S.V. (2015). Porody sil'skogospodars'kykh tvaryn Ukrainy. Istoriya, stan, perspektyvy rozvytku. Rozvedennia i genetyka tvaryn. 49, 44-57 (In Ukrainian).

Стаття надійшла до редакиії 7.02.2017 